\title{
Desafios e tendências da Comunicação Empresarial
}

\author{
Valéria Amoris*
}

BUENO, Wilson da Costa. Comunicação Empresarial: políticas e estratégias. São Paulo: Saraiva, 2009, 338 p.

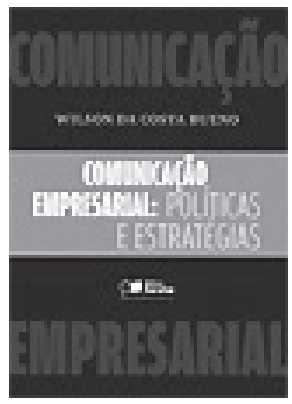

maior preocupação de quem toma contato com o livro
Comunicação Empresarial: politicas e estratégias pode ser
quanto a seu grau de informação e atualização, já que o tema parece esgotado. Mas o autor, o jornalista e professor Wilson da Costa Bueno - um dos mais renomados profissionais deste país, especializado não só nesta área, mas também em Jornalismo Científico; Ambiental; Comunicação em Agrobusiness e Comunicação para a Saúde - é dono de uma dissertação ímpar; atento a assuntos que rendem ótimas análises, observações e críticas que vão direto "na jugular". Inclusive, a característica mais forte de seu texto é justamente, seu tom desafiador e crítico, tornando-se sua marca.

Este trabalho pode ser considerado resultado do sucesso dos temas analisados no livro anterior, "Comunicação Empresarial no Brasil: uma leitura crítica", lançado em 2005. Porém, o autor vai além. Explora com mais precisão a produção intelectual; manifestando suas angústias e inquietações sobre a forma com que a comunicação empresarial vem sendo trabalhada no Brasil.

Organizado em 11 capítulos, acompanhados de textos complementares para leitura e debate em sala de aula, o livro serve como apoio didático, porém não se destina apenas a estudantes de comunicação, mas também aos professores, profissionais de organizações públicas, privadas e do Terceiro Setor. A linguagem utilizada

\footnotetext{
* Mestranda do Programa de Mestrado em Comunicação da Universidade Municipal de São Caetano do Sul - USCS. E-mail: valeria-amoris@uol.com.br.

${ }^{1}$ BUENO, Wilson da Costa. Comunicação Empresarial no Brasil : uma leitura crítica. São Paulo: ALL PRINT, 2005, 200 p. (Coleção Comtexto de comunicação).
} 


\section{VALÉRIA AMORIS}

é simples e objetiva, em alguns momentos, irônica e debochada, o que reforça o tom crítico do autor. A maneira como escreve é inconfundível e a posição desafiadora sempre presente em seus textos ganha uma dimensão jornalística invejável, devido à sua visão dinâmica, que valoriza a diversidade de idéias e a pluralidade de opiniões. E dessa pluralidade, os capítulos expostos foram compilados na seguinte ordem: "Comunicação Empresarial: conceitos e trajetórias"; "Comunicação e inteligência empresarial"; "Comunicação e estratégia: refinando conceitos"; "Comunicação interna e processo de gestão"; "Comunicação e cultura na Wikieconomia"; "Planejando a comunicação para enfrentar a crise"; "Comunicação e gerenciamento de imagem"; "Transformando a mídia em parceira"; "A Sala de Imprensa na web: conceito, estrutura e atributos básicos"; "Comunicação Corporativa, governança e sustentabilidade"; e "Construindo uma política de Comunicação Empresarial".

Logo na apresentação do livro, o autor já sinaliza uma tendência, afirmando que "a comunicação empresarial está definitivamente atravessando uma nova fase [...] e os executivos da área estão sendo retirados da zona de conforto, sendo obrigados a rever conceitos, a desenvolver metodologias de avaliação de seus trabalhos e, sobretudo, a reposicionar valores e estratégias para compatibilizar os interesses das organizações com os das comunidades em que elas se inserem".

Bueno confirma que, no Brasil, apenas algumas organizações possuem uma política de comunicação estruturada que sejam adequadas às estratégias da empresa. Estratégias essas que, no mundo dos negócios, aqueles que possuem documentos com dados confiáveis, não só de cunho financeiro, mas, sobretudo com um panorama quantitativo sociocultural estará incentivando novas culturas que caminharão junto às constantes mudanças da sociedade. Outras questões observadas pelo autor que vão do $1^{\underline{o}}$ ao $8^{\text {o }}$ capítulo, são referentes aos riscos de governança ligados aos negócios da empresa; interatividade e a convergência das possibilidades de participação dos funcionários na comunicação interna. Nota-se que as organizações mobilizariam mais que uma nova cultura de negócios, em que a coletividade e o compartilhamento de informações seriam a base para a construção de novos cenários, 
onde as empresas estariam comprometidas com a comunidade e seriam percebidas positivamente por ela. Analisando deste modo, justo dizer que não é fácil discorrer sobre a integração das práticas comunicacionais existentes nas corporações, por meio de jornal interno; assessoria de imprensa; intranet; marketing; entre tantos outros segmentos que surgem para favorecer a imagem da empresa junto à mídia e a população.

Como Bueno aborda nos capítulos mencionados acima, entre os aspectos mais polêmicos encontra-se a comunicação na web. De maneira contundente, a narrativa do livro pressupõe que a comunicação on line é má utilizada pelas corporações, já que os gestores ainda não notaram que se trata de uma ferramenta que rompe com a barreira do tempo e do espaço e instaura uma nova ordem. É importante perceber que ela não altera apenas o ritmo dos relacionamentos, mas cria espaços novos de convivência, redimensiona hábitos de consumo e circulação de informações e, sobretudo, potencializa, para as empresas, novas oportunidades de negócios.

Ou seja, o mundo muda, logo as empresas também têm que aprender a mudar. Partindo desse panorama, Bueno esclarece essas mudanças facilmente e a partir do 9a capítulo (até o fim do livro) trabalha com precisão os prós e contras das novas ferramentas comunicacionais inseridas no mercado empresarial. Afirma, porém, que esses novos mecanismos desagradam o gosto dos empresários do momento, que em geral não admitem o fato de não terem conseguido dominar os formatos propostos pelas novas mídias. Dessa forma, fazem uma mera transcrição dos discursos tradicionais, sem atentar que não foi só o processo de comunicação que sofreu mudanças, mas sim, - e pode-se considerar a maior e mais importante mudança de todas - a evolução do cliente para o cidadão.

Nas 338 páginas, Bueno conversa com seu leitor o tempo todo. Em suas narrativas, procura, sempre, chamar a atenção a uma reflexão. Neste livro, além de manter esse objetivo, ele, estimula para que haja um diálogo visando a mudanças significativas sobre o papel dos comunicadores empresariais. 